\title{
Education and Socialization
}

\author{
Matthias Grundmann
}

\begin{abstract}
Education and socialization both refer to processes of intra- and intergenerational transmission of knowledge and practices. In line with Parsons, Germanspeaking sociology tends to think of education-as a secondary mode of socialization-in terms of an institutional arrangement that imparts universal competence and knowledge. Consequently, educational research in German-speaking countries concentrates on the analysis of educational school systems. Socialization research, by contrast, tends to focus on all those processes that are embedded in the relationships that make up the lifeworld. These relationships are also constitutive of education, which builds on socialization. This review of the German-speaking research in the sociology of education and the sociology of socialization follows this division. What becomes apparent is that socialization research is fundamental for a deep understanding of the social constitution of education and the construction of social inequality.
\end{abstract}

Keywords: Education, socialization, development, social construction, macro-microsociology

\section{Introduction}

Education and socialization are two terms that address, each in specific ways, processes of the intergenerational transmission of knowledge. Education is mainly used to describe differential educational programs in institutional arrangements and the resultant opportunities for educational attainment. Socialization, on the other hand, refers to those primary social experiences that are inherent to intergenerational social relationships. From this perspective, socialization precedes all education. Parsons (1964) of course distinguished between primary and secondary socialization. This differentiation is still useful in addressing the relationship between socialization and education, as is the objective of this article. While primary socialization takes place in particular, lifeworldly reference groups, secondary socialization refers to institutionalized and hence socially regulated agents of socialization, such as schools. The universalistic educational aspirations pursued by the latter thus always build on the primary processes of socialization occurring in the former. This distinction enables us to describe the respective fields of research in education and socialization research as mutually intertwined, intergenerationally transmitted processes of generating understanding and knowledge that are, however, embedded in different-lifeworldly or systemic-contexts. In both cases, it is also important to note how these differential

Note: All quotes from German sources have been translated by Andrea Tönjes.

Ә OpenAccess. (c) 2021 Matthias Grundmann, published by De Gruyter. (c))BY-NC-ND This work is licensed under the Creative Commons Attribution-NonCommercial-NoDerivatives 4.0 License. 
socialization processes are influenced by living conditions related to social background. A key feature of education and socialization research is thus that it provides findings that are crucial to the analysis of social inequalities.

When we consider both national and international education research against this backdrop, the first observation is that the sociology of education, with its dominant focus on quantitative analyses of education systems and their inequality-generating structures, primarily centers on the analysis of institutionalized educational arrangements and structures and their significance for social change. This also involves recognizing life-course-specific opportunity structures that enable individual actors to position themselves within a system of social inequality (Otte/Boehle/Kunißen, SOCIAL INEQUALITIES-EMPIRICAL FOCUS, this volume). Socialization research, by contrast, highlights the underlying social relationships that are rooted in lifeworlds and play a significant role in developing agency in general. This field of research thus focuses on analyzing processes of child-rearing and on the individual as well as socio-cultural generation of knowledge. This "division of labor" between education and socialization research is also due to the fact that drawing a clear-cut distinction between socialization and education is virtually impossible. Primary and secondary processes of socialization are far too intertwined and play a much too significant role in understanding social processes of education.

The present overview of the current state of education and socialization research in German-speaking countries thus focuses, first of all, on mainstream research in the sociology of education, which places its analytical emphasis on school-based education and mainly inquires into secondary processes of socialization (2). This overview will serve as our point of departure to show how socialization research contributes to a more in-depth analysis of educational processes rooted in the lifeworld and to outline how socialization and education research benefit from each other (3). What becomes evident is that socialization research in particular extends beyond the narrow focus of empirical education research to address those "educational processes" that precede any form of organized education provided by society. This leads to a holistic, anthropologically grounded understanding of education (4), and German-speaking socialization research contributes key arguments to the international professional debate on this issue.

\section{Education as Institutionalized (Secondary) Socialization}

There is consensus in empirical education research that educational processes in modern societies can be described as secondary processes of socialization, especially when we look at the institutional arrangements in which they take place (Brooks, McCormack and Bhopal, 2013). In this vein, mainstream research in the sociology of education focuses on school as an agent of socialization. This holds true both for 
German-speaking countries and internationally. This research focus coincides with the specification of what constitutes the substance of the discipline as laid out in the ASA journal Sociology of Education. The journal views itself as a "forum for [...] research that examines how social institutions and individuals' experiences within these institutions affect educational processes and social development" (https://journals.sagepub.com/home/soe, 10.08.2018). This moves social systems of education into the spotlight of sociology-of-education research. It examines how education is anchored in its respective national contexts and structural-functionally embedded within the system of social inequality. This is why analyses of school-based education account for the bulk of publications in the sociology of education, both in the national and international research discourse (see, e.g., the Handbook of the Sociology of Education, Hallinan, 2006). German-speaking education research has contributed considerably to the international debate in this respect, not least because the German education system has been a model for the global expansion of school-based educational arrangements.

International assessments of educational attainment, such as the Programme for International Student Assessment (PISA) study, can be seen as a reference and anchor point for German-speaking education research to connect with the international research discourse (Maaz, Baumert and Neumann, 2014). The significance of the PISA study for international empirical education research has been underlined time and again, while it has also been emphasized that research demonstrating that educational success in Germany depends on social background has provided important stimuli for international education research as well. Particularly important in this respect are the traditional structures of Germany's education system, such as the three-tier system of secondary schooling (Hauptschule, Realschule, Gymnasium) ${ }^{1}$ and the two forms of post-secondary education, its dual system of vocational education and training and higher education. They have served as a blueprint for many other national education systems. At the same time, the German education system is marked by early selection based on academic achievement (after primary school), which is decisive for the strong persistence of educational inequality, which has been corroborated by many national and international studies. We thus encounter an ideal field for sociological education research, a field that has the status of a historical model and is also well suited to a detailed analysis of the selection dynamics, especially regarding the logics of producing and reproducing educational opportunities associated with specific social backgrounds and how these logics are anchored in educational policy. That is why much of the German-speaking literature in the sociology of education can be characterized by keywords such as educational expansion, educational mobility, educational privileges, and institutionalized inequalities. This research focus ties in with the international debate as described by Apple (2010), for

1 In the German system, Hauptschule is the lower track of upper secondary education, Realschule the intermediate track, and Gymnasium the advanced track that qualifies for higher education. 
example. All these studies analyze-and sometimes criticize-the education system and its political logic of reproduction, which is primarily governed by meritocratic principles. This criticism of a technocratic approach to education becomes obvious in Hartong's book (2012) Basiskompetenz statt Bildung? (Basic Competence Instead of Education?) on fostering basic competence instead of inculcating education, which shows how PISA changed the German school system. The PISA study was meant to measure students' actual basic competences and hence their educational potentials in an empirically meaningful way to facilitate international comparison. However, it also brought to light the massive institutional logics of governance and reproduction inherent in those educational careers, suggesting that the proper social background matters more than competence-which also exposes the principles by which the state evaluates educational success. What PISA has demonstrated is therefore the functional appropriation of education by politics and the economy. This approach thus addresses issues such as social and educational policy programs, issues of justice and sub-cultural educational needs (for instance, for the promotion of lifelong learning) but also opportunities for the commodification of education. An example of such a nuanced view of education as a functional instrument of governance is the volume Bildung und Klassenbildung (Education and Class Formation), edited by Müller and Reitz (2015). In addition to discussing the paradigms in inequality research that are relevant from a sociology-of-education perspective, the book identifies the fault lines of current education policies and ideologies and critically examines the opportunities for social advancement via higher education.

The volume Die Organisation von Bildung. Soziologische Analysen zur Schule, Berufsbildung, Hochschule und Weiterbildung (Organizing Education. Sociological Analyses on School, Vocational Training, Higher Education, and Professional Development), edited by Leemann et al. (2016), also provides a good overview of empirical research in the sociology of education that has been emerging in German-speaking countries along these lines. The fields of study presented in this book show that the German-speaking research literature offers a contemporary analysis of education systems, organizations, and structures as well as of the related ways of regulating and channeling different segments of the population. This invariably involves issues regarding the social development of the respective state-organized education systems and, consequently, of the different educational opportunities and opportunity structures associated therewith. Empirical research in particular has provided us with numerous publications on these issues, all of which document the great importance of education for social status, personal development, and the realization of life chances. They all confirm that education is of tremendous significance for generating inequalities and thus a key instrument in allocating and distributing social status in highly differentiated modern societies. In many ways, they also highlight the various theoretical approaches to society and inequality (e.g., by Boudon, Coleman, Bourdieu) on which the sociology of education draws-across all ideological and methodological differences that inform it otherwise. This work also connects with the international 
state of research and discussion, as documented by Sadovnik and Apple (2007), for instance.

Most of these publications, however, adhere to a macro-sociological-and thus quantitative-analysis of education, even though they take into consideration processes of acquiring education that occur on different levels of action as well as processes of the inter- and intragenerational transmission and transformation of practical knowledge. The volume Education as a Lifelong Process. The German National Educational Panel Study, edited by Blossfeld, Roßbach, and von Maurice (2011), is an instructive example that illustrates the German-speaking contribution to international education research in a particularly impressive manner. Here we find a detailed analysis of the societal significance of education, both with regard to social change and as an intergenerational transmission belt for individual conducts of life in highly differentiated modern societies. In short, with some minor exceptions, nearly all pertinent German-language publications in the sociology of education conceive of education as a dimension of inequality that determines opportunities in life. These publications are marked by a detailed analysis of macrostructural "determinants" of education as a powerful human resource, which is arguably subject to social change, and this change needs to be documented.

Most German-language publications on education thus refer to a sociology of education that expands its horizon of knowledge by focusing on education's potential to transform society. They illustrate that sociological research on education is also distinguished by its critical reflections on the social embeddedness of school-based education and the associated economic and political impact on the conduct of life, employment, career prospects, leisure activities, and media consumption and design. The probably most comprehensive volume presenting such a nuanced perspective on "educational processes" in German-speaking countries has been published by Maaser and Walther (2011). This book describes education as a process of practical appropriation and modification of the world, of developing craftsmanship as well as scientific understanding, of transmitting culturally generated stocks of knowledge, of perception and imagination, and as a highly diversified process in which different individual and social actors appropriate and shape differential living conditions. A similarly broad approach to the sociology of education also characterizes publications on the theory of education that emphasize the social significance of education and its influence on social change. One example of this is the volume Recht auf Bildung (Right to Education), edited by Overwien and Prengel (2007), which also addresses the historical anchoring of education as a human right. It brings to the forefront issues such as the societal appreciation and recognition of education as well as questions of power within and by means of education. Several studies also discuss the implications of education for politics and social theory. These include, for instance, Wissenschaft oder Dummheit? Über die Zerstörung von Rationalität in den Bildungsinstitutionen (Science or Ignorance? On Destroying Rationality in Educational Institutions) by Demirovic (2015) or the collection Bildung MACHT Gesellschaft (Education POWER(S) Society), edited by Sandoval et al. (2011). They pick up on the international discourse on ed- 
ucation as compiled in Apple's (2010) The Routledge International Handbook of the Sociology of Education or Brooks, McCormack, and Bhopal's (2013) Contemporary Debates in the Sociology of Education.

\section{Education as a Socialization Practice}

All of the aforementioned publications share an approach to education that perceives it as being socially anchored in secondary entities of socialization, that is, in educational organizations and institutionalized educational arrangements. What they fail to consider is sociocultural and therefore milieu-specific processes of education. This provides the point of departure for socialization research with a focus on social stratification, and especially on the interplay between education in lifeworldly and institutional contexts. This line of research conceptualizes socialization and education as a mutually fruitful configuration of lifeworldly experience and school requirements. In this way, the sociogenesis of education can be reconstructed as the socially embedded development of knowledge, understanding, and skills (Grundmann, Steinhoff, and Edelstein, 2011; Grundmann and Steinhoff, 2014). This sheds light on the anthropological foundations of how humans generate knowledge and action, that is, on cultural practices of education that emerge as a result of socialization through human relations. From these foundations then derive the conceptions of and discourses on what people must learn, develop, and acquire in order to adequately position and realize themselves in highly differentiated societies. An illustrative example of this approach is the volume Education, Welfare and the Capability Approach. A European Perspective, edited by Otto and Ziegler (2010). Here the focus is on education as a resource for agency. This analytical perspective builds on the international state of research on agency and is also a characteristic feature of education research that draws on Bourdieu's concept of habitus. The volume Schülerhabitus. Theoretische und empirische Analysen zum Bourdieuschen Theorem der kulturellen Passung (Student Habitus. Theoretical and Empirical Analyses Based on Bourdieu's Theory of Cultural Fit), edited by Helsper, Kramer, and Thiersch (2014), presents in detail how socialization and education can be conceived of as a more or less successful fit between background-specific and academic requirements that young people have to meet and reconcile. A particularly detailed account of this nexus between socialization and education is also provided in studies on educational intergenerational relationships (e.g., Helsper et al., 2009). They illustrate how socialization practices and education processes are transmitted within and between generations. Their findings are relevant to international research not least because they confirm the considerable degree to which these relationships of fit determine young people's educational and life orientations not only within but also outside the school setting. They are thus also particularly illustrative of the challenges and demands that youths have to come to terms with in postmodern sociality. An outstanding demonstration of such detailed socialization and education research is the volume Teenies und ihre 
Peers. Freundschaftsgruppen, Bildungsverläufe und soziale Ungleichheit (Teens and Their Peers. Friendship Groups, Educational Careers, and Social Inequality), edited by Krüger, Köhler, and Zschach (2010). This is because it not only finds that differentiated education generates inequality, but its considerations along the lines of action and practice theory also bring into focus the specific educational careers and their significance for identity development among adolescents and young adults (and peers in general) as well as the segmented educational landscapes that are constitutive of the German education system. In short, this approach also addresses processes of educating and socializing oneself that take place in joint experience and action on and by means of specific educational occasions. The emerging trend is that of a sociology of education informed by a critical view of practice and culture, which also touches upon changes in life-course regimes and in the arenas of education and socialization as a result of multiple differentiation in postmodern and global society.

Such a broad approach to socialization research that takes into account social stratification increasingly also directs attention to the creative, post-pragmatic nuances that characterize educational programs, arrangements, ideas, paradigms, and-last but not least-individual actors' potential for action. What becomes evident here is that the secondary processes of socialization, and therefore the institutionalized processes of education, are to an ever greater degree marked by an orientation toward agency. This also involves a "practical turn" and thus prompts the following questions: What are the actual characteristics of socialization and education practices? And how do they materialize in a co-constructive manner? This perspective calls for a view of education and socialization processes informed by social theory. A book that stands out from the usual treatment of education is the volume Bildungspraxis (Educational Practice) by Alkemeyer, Kalthoff, and Rieger-Ladich (2015) as it conceptualizes education as a practice of cultivating bodies, spaces, and objects, and hence as a complex process involving the "educability" of human activities. What comes into focus is that education takes place in the form of a continuous appropriation of the world and attribution of meaning to the world as people relate to their (physical, spatial, and material) environment through performative as well as modifying acts. In this vein, socialization and education processes can be understood as incessant processes of reproducing and reshaping the living conditions that are encountered. In this context, the German-speaking research literature draws on recent approaches in social theory, for instance, actor-network theories and other relational action theories as well as on corresponding approaches that have hitherto rarely been tapped in these fields of research. These studies also tie in with the current international debate, as documented, in particular, by Apple (2010) in The Routledge International Handbook of the Sociology of Education. There we find the outlines of a sociology of education that critically scrutinizes social backgrounds, relations of power, and the development of social stocks of knowledge.

Such a socially critical sociology of education informed by practice and network theories illustrates that all education rests on underlying socialization (as acts of jointly performing and producing practices and power relations). This is because 
socialization invariably involves the performative appropriation and attribution of experiential and living spaces that individuals not only preconceive in their minds but constantly create anew in interaction, thereby producing distinctive stocks of knowledge and discourses. The focus of education and socialization research is then geared toward the practical performance of joint physical activities with the purpose of joint action. This kind of socialization research shifts the focus to co-operative and co-constructive practices that are constitutive of socialization in general (Grundmann, 2018). Consequently, socialization and education can no longer be simply defined as primary and secondary processes. They take place simultaneously and are always interdependent, specifically by means of engaging in a collectively shared practice of the conduct of life and hence by jointly experiencing, exploring, and acquiring cultural techniques (including the intergenerational transmission of agency and knowledge). Socialization is then not primarily interpreted as a process of individuation or of adapting to given social conditions (as implied in the concept of "education") but is rather conceptualized as an expression of the socially desirable development of personality and social practices that precedes all education and therefore must conform to the institutionalized educational requirements. This also marks a nexus between research on education and on socialization-which is the hallmark of German-speaking socialization research. Accordingly, most German-speaking studies on socialization pursue an analytical approach that considers social stratification and thus direct their attention, similar to education research, to different living conditions and individual dispositions along with their effects on individual (personality) development. The Handbuch Sozialisationsforschung (Handbook Socialization Research), edited by Hurrelmann et al. (2015), provides a detailed overview of current socialization research and is unique in terms of its comprehensive discussion of the many facets of the issue. This volume compiles basic theoretical considerations on the social constitution and development of human interaction and relations that lay the groundwork for the entire field of education research. Education, we might say, represents a special case of socializing acts, the socio-cultural product of engaging in joint action by which humans adapt to and create similarity between one another both within and across generations. Socialization research therefore addresses those basic processes of transmission and social co-construction that precede all education.

\section{Socialization as Social Cultivation}

The described forms of differentiated and theory-based research on socialization and education, a characteristic feature of the German-speaking research landscape, is rarely found in the current international discourse-and if it is, then not in sociology but in psychology or education-science literature (e.g., Grusec and Hastings, 2007). One of the main reasons for this is that empirical-and for the most part quantitative-research in the sociology of education predominantly focuses on life-course structures and the individual conduct of life. While these studies, as outlined above, 
trace in detail the likelihood of educational opportunities being passed on to the next generation as well as the various ways in which family resources and personal dispositions influence educational processes in different settings (cf. Settersten and Owens, 2002), they adhere to an analytical perspective that conceives of socialization as a process of attuning oneself to existing lifeworlds. This, however, also entails an analytical narrowing of education and socialization to processes of individual development by neglecting those constitutive social practices that only take shape in and through socialization processes. This is why German-speaking socialization theorists in particular discuss the grounding of sociality and social practice in and through socialization. From their perspective, this aspect hardly seems to matter anymore in international research discourse.

Current sociological socialization research in German-speaking countries expands this perspective by incorporating social and practice theories of the kind mentioned above. In addition to analyzing social imprinting and integration requirements from a global perspective, this research mainly centers on the processes that shape changing social relationships. In doing so, this approach addresses issues such as the development of practical knowledge and procedures, the individual development of competences and agency, the collective formation of values and of principles and guidelines for action, as well as of associated socio-cultural beliefs regarding gender relations, role arrangements, and identity and habitus formations. All of this is discussed along the lines of educational issues related to the family, religion, social mobility, or to the diversity and social differentiation of life courses. The entire set of questions is not only addressed with regard to the cognitive level but also in terms of emotions and feelings, bodies, media, networks, practices, and cultures. Good examples of this approach are King's (2002) Die Entstehung des Neuen in der Adoleszenz. Individuation, Generativität und Geschlecht in modernisierten Gesellschaften (The Emergence of the New during Adolescence. Individuation, Generativity, and Gender in Modernized Societies) and King and Flaake's (2005) book on male socialization, which also focuses on such processes of co-construction. Both books describe how the younger generations are faced with new demands and challenges as they are called upon both as individuals (individuation) and as generatively bound members of (same-gender) reference groups. These demands and challenges cannot simply be reduced to identity problems. It is rather that postmodern subjects are called upon to conquer their own worlds-worlds that can be established and eventually marketed as a "new culture." What comes into focus here are not only the various institutional and non-institutional agents of socialization, such as school, family, and peers, but also educational discourses and materialities (e.g., computers, chat rooms, Internet forums) that are produced in socio-cultural (or technological) processes and act as agents of interaction, as it were. This, however, moves to the center of attention in sociological education research the processes by which changing conditions and agents of socialization shape and change social relationships. In this view, education becomes visible as a process of shaping social relationships and practices in coordinated action between co-present participants in which the latter develop a sense of 
collectivity and shared identity. Recent approaches in childhood research that emphasize the proactive and autonomous influence of youths as educational actors (Kelle and Tervoren, 2008) refer to similar connotations of socialization practices as discursive products of the continuous need to invoke and shape references and conceptions of everyday action.

The German-language debate thus opens up to an interdisciplinary field of research that conceives of socialization and education processes as taking place in ongoing processes of living together, that is, as part of interaction, communication, and relationship practices that are a major factor in generating inequality. Here, too, current German-speaking socialization research connects with the international research debate, for instance, on how social inequality affects childhood (see Lareau's Unequal Childhoods, 2003).

Looking at the diverse and recurring gender and childhood practices from a constitution-theoretical (e.g., social constructivist) perspective also has consequences for what we define as the substance of socialization as human development. Socialization and education, then, can no longer simply be reduced to socially predetermined structural parameters to which individuals adapt and conform in childhood and adolescence. What becomes manifest instead is that socialization and education play a key role as theoretical foundations in social theories seeking to identify those social processes of co-construction by which childhood, adolescence, and gender are recurrently generated "anew" as a result of discursive dynamics. Tracing how imaginaries and actual opportunities for shaping the conduct of life mutually permeate each other draws our attention to basic processes of socialization as co-constructive cooperation and the co-constructive formation of cultural practices-over the whole life course. If we conceive of socialization and education processes as practical action performed in multiple and, in most cases, also highly diverse contexts, we gain an understanding of how they lead to the emergence of cultural practices that shape both material and immaterial living conditions. These practices are, as stated above, fundamental to the intra- and intergenerational generation and transmission as well as to the continuous advancement of understanding and stocks of knowledge. Given the international debate, a distinctive feature of German-speaking socialization research is precisely that it sheds light on these constitutive processes. Pertinent publications in this respect are, for instance, Wagner's (2004) two-volume work on structural socialization theory, Beer's (2007) epistemological considerations on socialization, Sutter's (2009) book on interactionist constructivism, or my own publications on socialization (e.g., Grundmann, 2006, 2018). They all share an approach that sees socialization as being constituted in an interactive process that generates knowledge and action by social reference to others. Socialization thus underpins those educational processes that are, in their specific historical form, the research object of the sociology of education as apparent in the aforementioned (macro-)structural analyses of education. These publications further demonstrate that socialization is not only crucial for the inter- and intragenerational transmission of practical or intellectual knowledge that is constitutive of educational processes. Socialization processes also 
hold a creative potential that not only goes beyond the existing social conditions but actually prompts their change (e.g., through the dynamics of subjectification). Grounding educational processes in socialization theory in this way directs attention to the social-theoretical works in network and practice theory mentioned above.

Günter Dux's (2017) recent book Die Evolution der humanen Lebensform als geistige Lebensform (The Evolution of the Human Form of Life as a Spiritual Form of Life) offers what is perhaps the most comprehensive view on education that such a basic theoretical perspective might yield. According to Dux, human beings become "cultural beings" by engaging in the various activities that shape their lives. These activities find their differential expression in acting and thinking-specifically, in conceptions of the practices and structures of generating understanding and knowledge that are to be developed. Language is the medium for transmitting these conceptions within and between the generations. In the course of this, educational processes-in their onto-, socio-, and historiogenesis-interweave into a peculiar medium-based, cognitively processed form of generating knowledge, which, at the same time, has to stand the practical test of real life. We then refer to education as a process in which opinions are formed, family relations forged, communities built, and so on. This perspective conceives of education as a historical process of acquiring knowledge, but one that nevertheless must take place anew and thus form anew in every individual. The primary insight to be gained from theoretical publications of this kind is that they refer to a "constructive performance," specific to the human species, that underlies all empirical manifestations of socialization and education (Grundmann, 2018). However, this understanding of education does not interpret education in a deterministic manner as being governed by a specific rationality underlying the conduct of life or by a social functional system. Instead, education is rather seen as the product of a recurring process of "relating to the world" by which humans jointly construct, appropriate, shape, vitalize, and develop their spheres of living as well as the material and immaterial features that characterize these spheres. This leads us to an interpretation of education as an expression of an evolutionary cultural performance that humans employ in their conduct of life to express themselves as cultural beings.

\section{Conclusion}

In the German-speaking and international literature alike, sociological education and socialization research, as outlined in this article, represents a highly differentiated field of study that seeks to trace the most diverse-including sub-cultural and intangible-meanings that constitute the substance of socialization as the basic, coconstructive mode of shaping social relationships and of education as the cultural, coconstructive, and practical shaping of living conditions. It brings to light the socialization practices and formation processes that lie beneath the layer of education provided in institutional settings. This perspective describes socialization and education as highly subtle, multi-faceted, and mutually fruitful performances with social, 
lifeworldly, and practical implications for the individual and collective conduct of life. The sociology of education's traditional focus on institutional educational arrangements and organizations is significantly expanded by empirical socialization research with an emphasis on those constitutive primary educational processes that emerge in socialization-related interaction, in relationship practices, and in reaction to different agents of socialization. From the perspective of socialization and education theory, we might state in a nutshell that humans access the world through meaningful, cognitively and interactively transmitted conceptions and images of the state of the world and seek to realize themselves by shaping the latter in their own "image." The institutional design of education in modern societies subscribes to a narrow conception of education because it is content with the status quo of a differentiated sociality and ignores the question of how educational occasions in everyday life and educational processes in human interaction could give rise to alternative educational paths and opportunities that have not yet been disavowed by the structural-functional logics of utility. This vests research with significance that conceives of education as a cultural performance that must form again and again in acts of socialization and exposes the "blind spots" of a narrow approach to education research in general and to sociological education research in particular. What is being neglected is above all the sociogenetic processes of education that also disclose to us the kind of education that is possible when we describe education in terms of recurring acts of recognizing opportunities for shaping and appropriating the world. When looking at education from such a basic theoretical perspective, we can also discern the outlines of a sociological theory of socialization and education that acknowledges socialization and education as fundamental expressions of human cultural development, regardless of their different embeddedness in social structures. From this vantage, we can also challenge the structural-functional and, often enough, "inhumane" ways in which educational institutions convey education and show what alternative educational practices and processes might look like. "Alternative" refers to options other than the impositions of a hypertrophic sociality that reduces education to a piece of information and a resource instead of highlighting its potential to shape lives, not least also for mastering the challenges and demands of such a hypertrophic sociality on a global scale. This refers to a research desideratum that sociological socialization research should address: research that exposes the constitutive practices of social formation that precede education of any kind.

\section{References}

Alkemeyer, T.; Kalthoff, H.; Rieger-Ladich, M., Eds. Bildungspraxis. Körper - Räume - Objekte; Velbrück: Weilerswist, 2015.

Apple, M. W., Ed. The Routledge International Handbook of the Sociology of Education; Routledge: London, 2010. 
Beer, R. Erkenntniskritische Sozialisationstheorie. Kritik der sozialisierten Vernunft; VS: Wiesbaden, 2007.

Blossfeld, H.; Roßbach, H.; von Maurice, J., Eds. Education as a Lifelong Process. The German National Educational Panel Study (NEPS); Springer VS: Wiesbaden, 2011.

Boronski, T.; Hassan, N.; Eds. Sociology of Education; Sage: Los Angeles, 2015.

Brooks, R.; McCormack, M.; Bhopal, K.; Eds. Contemporary Debates in the Sociology of Education; Palgrave Macmillan: Basingstoke, 2013.

Demirovic, A. Wissenschaft oder Dummheit? Über die Zerstörung der Rationalität in den Bildungsinstitutionen; VSA: Hamburg, 2015.

Dux, G. Die Evolution der humanen Lebensform als geistige Lebensform; Springer: Wiesbaden, 2017.

Grundmann, M. Sozialisation. Skizze einer allgemeinen Theorie; UVK: Constance, 2006.

Grundmann, M., Social Construction Through Socialization. The Perspective of Constructivistic Socialization Theory. In Social Constructivism as Paradigm; Pfadenhauer, M., Knoblauch, H.; Eds.; Routledge: Abingdon/New York, 2018; 91-104.

Grundmann, M.; Steinhoff, A. Communication Experiences: A Constitutive Principle in Pupils' Socialization of Agency. Learning, Culture and Social Interaction (LCSI), 2014, 3, 177-183.

Grundmann, M.; Steinhoff, A.; Edelstein, W. Social Class, Socialization and Capabilities in a Modern Welfare State: Results from the Iceland Longitudinal Study. In Closing the Capability Gap. Renegotiating Social Justice for the Young; Leßmann, O., Otto, H.-U., Ziegler, H., Eds.; Barbara Budrich Publisher: Farmington Hill, 2011; pp 233-251.

Grusec, J. E.; Hastings, P. D., Eds. Handbook of Socialization. Theory and Research; Guilford Press: New York, 2007.

Hallinan, M. T., Eds. Handbook of the Sociology of Education; Springer: New York, 2006.

Hartong, S. Basiskompetenzen statt Bildung? Wie PISA die deutschen Schulen verändert hat; Campus: Frankfurt am Main, 2012.

Helsper, W.; Kramer, R.; Thiersch, S., Eds. Schülerhabitus. Theoretische und empirische Analysen zum Bourdieuschen Theorem der kulturellen Passung; Springer VS: Wiesbaden, 2014.

Helsper, W.; Kramer, R.; Hummrich, M.; Busse, S. Jugend zwischen Familie und Schule. Eine Studie zu pädagogischen Generationenbeziehungen; Springer VS: Wiesbaden, 2009.

Hurrelmann, K.; Bauer, U.; Grundmann, M.; Walper, S., Eds. Handbuch Sozialisationsforschung. 8. Auflage; Beltz Juventa: Weinheim/Basel, 2015.

Illouz, E., Ed. Wa(h)re Gefühle; Suhrkamp: Berlin, 2018.

Kelle, H.; Tervooren, A., Eds. Ganz normale Kinder. Heterogenität und Standardisierung kindlicher Entwicklung; Beltz Juventa: Weinheim/Basel, 2008.

King, V. Die Entstehung des Neuen in der Adoleszenz. Individuation, Generativität und Geschlecht in modernisierten Gesellschaften; VS: Wiesbaden, 2002.

King, V.; Flaake, K., Eds. Männliche Adoleszenz. Sozialisation und Bildungsprozesse zwischen Kindheit und Erwachsenensein; Campus: Frankfurt am Main, 2005.

Krüger, H.; Köhler, S.; Zschach, M. Teenies und ihre Peers. Freundschaftsgruppen, Bildungsverläufe und soziale Ungleichheit; Barbara Budrich: Opladen, 2010.

Lareau, A. Unequal Childhoods. Class, Race, and Family Life; University of California Press: Berkeley, 2003.

Leemann, R. J.; Imdorf, C.; Powell, J. J. W.; Sertl, M., Eds. Die Organisation von Bildung. Soziologische Analysen zu Schule, Berufsbildung, Hochschule und Weiterbildung. Beltz Juventa: Weinheim/Basel, 2016.

Lohmann, I.; Rilling, R. Die verkaufte Bildung. Kritik und Kontroversen zur Kommerzialisierung von Schule, Weiterbildung, Erziehung und Wissenschaft; Leske + Budrich: Opladen, 2002.

Maaser, M.; Walther, G., Eds. Bildung. Ziele und Formen. Traditionen und Systeme. Medien und Akteure; J. B. Metzler: Stuttgart, 2011. 
Maaz, K.; Baumert, J.; Neumann, M., Eds. Herkunft und Bildungserfolg von der frühen Kindheit bis ins Erwachsenenalter. Springer VS: Wiesbaden, 2014.

Moen, P.; Elder, G. H.; Lüscher, K., Eds. Examining Lives in Context: Perspectives on the Ecology of Human Development; APA: Washington, 1995.

Müller, H.; Reitz, T., Eds. Bildung und Klassenbildung. Kritische Perspektiven auf eine Leitinstitution der Gegenwart; Beltz Juventa: Weinheim and Basel, 2015.

Otto, H.-U.; Ziegler, H., Eds. Education, Welfare and the Capability Approach. A European

Perspective; Barbara Budrich Publishers: Opladen/Farmington Hills, 2010

Overwien, B.; Prengel, A., Eds. Recht auf Bildung; Barbara Budrich: Opladen, 2007.

Parsons, T. Social Structure and Personality; Free Press: Michigan, 1964.

Sadovnik, A. R.; Apple, M. W., Eds. Sociology of Education. A Critical Reader; Routledge: New York, 2007.

Sandoval, M.; Sevignani, S.; Rehbogen, A.; Allmer, T.; Hager, M.; Kreilinger, V., Eds. Bildung MACHT Gesellschaft; Westfälisches Dampfboot: Münster, 2011.

Schneider, B., Ed. Handbook of the Sociology of Education in the $21^{\text {st }}$ Century; Springer International Publishing: Cham, 2018.

Settersten, R. A.; Owens, T. J., Eds. New Frontiers in Socialisation; Elsevier: Amsterdam, 2002.

Sutter, T. Interaktionistischer Konstruktivismus. Zur Systemtheorie der Sozialisation; Springer VS: Wiesbaden, 2009.

Torres, C.; Antikainen, A., Eds. The International Handbook on the Sociology of Education; Rowman \& Littlefield Publishers: Lanham/Boulder/New York/Oxford, 2003.

Wagner, H.-J. Sozialität und Reziprozität. Strukturale Sozialisationstheorie; Suhrkamp: Berlin, 2004. 